\title{
STUDY ON SOME HEMATOLOGICAL AND BLOOD BIOCHEMICAL PARAMETERS OF NEWLY INTRODUCED LAYER BREEDS DEPENDING ON THE LAYING PERIOD
}

\author{
A. Arnaudov ${ }^{*}$, A. Bochukov², P. Petrov², V. Gerzilov², D. Penkov ${ }^{2}$ \\ ${ }^{1}$ University 'Professor Dr. Asen Zlatarov', Burgas, Bulgaria \\ Department Public Health and Health Cares, Faculty of Biology, Plovdiv University 'Paisii \\ Hilendarski', Plovdiv, Bulgaria \\ ${ }^{2}$ Faculty of Agronomy, Agricultural University, Plovdiv, Bulgaria
}

\begin{abstract}
PURPOSE: To compare some major hematological and biochemical blood parameters of 3 newly introduced poultry breeds - Australorp, Marans and Araucana, during different stages of their egglaying period.

METHODS: Five blood parameters were investigated: hematocrit, hemoglobin, glucose, total protein and total cholesterol. A hundred blood samples were tested, collected at three laying stages - beginning, middle and end.

RESULTS: Statistically significant differences in the hemoglobin levels by sexes were established: in Marans breed (males - between 8.38 and 13.45; females - between 7.30 and $9.02 \mathrm{~g}^{*} \mathrm{dl}^{-1}$ ) and Araucana (males - between 9.17 and 13.65; females - between 9.08 and $9.40 \mathrm{~g}^{*} \mathrm{dl}^{-1}$ ).

The hematocrit levels in the males (from $23.16 \%$ in Marans to $40.88 \%$ in Australorp) were significantly higher than the levels in the females (from $23.72 \%$ in Marans to $30.48 \%$ in Australorp).

The blood glucose test of the cocks (from 32.07 in Marans to $40.88 \mathrm{mmol}^{* 1^{-1}}$ in Australorp) showed higher levels compared to the female (from 23.72 in Marans to $30.48 \mathrm{mmol}^{* 1^{-1}}$ in Australorp).

The total protein content in the layers' blood (between 5.97 in Araucana and $8.73 \mathrm{~g}^{*} \mathrm{dl}^{-1}$ in Marans) was higher compared to cocks.

The total cholesterol levels were, as follows: males - from 2.05 in Araucana to $3.49 \mathrm{mmol}^{*} \mathrm{l}^{-1}$ in Australorp; females - from 1.92 in Australorp to $6.573 .49 \mathrm{mmol}^{* 1^{-1}}$ in Araucana.

CONCLUSIONS: The variations in the investigated parameters in the blood are a result of the simultaneous effect of several factors - breed genetic differences, differences in egg-laying effort and degree of adaptation.
\end{abstract}

Key words: glucose, hematocrit, hemoglobin, layers, total cholesterol, total protein

\section{INTRODUCTION}

Monitoring the hematological and biochemical parameters of blood provides a clear picture of the health status, the degree of adaptation and the productive capacity of newly introduced poultry species and breeds (1). It is also known that those indices vary depending on the bird age and breed. Moreover, a large variation in blood chemistry in egg-type strains was established (2).

\footnotetext{
*Correspondence to: A. Arnaudov, University 'Professor Dr. Asen Zlatarov'- Burgas, Dep. Public Health and Health Cares; Plovdiv University 'Paisii Hilendarski', Faculty of Biology, Phone +359-889206757, arny87@abv.bg
}

Some biochemical blood parameters are largely affected by the physiological strain on the body that may be due to rapid changes in environmental conditions or to an intense commercial use. That effect can be observed in poultry $(3,4)$, especially in the period of intensive laying.

A significant portion of variations is also due to individual differences. According to (5) resolving the physiological and evolutionary consequences of individual variations represents an exciting challenge for the future. Campbell and Ellis (6) established that, during egg production, some wild avian can develop 
anemia (reduction in hematocrit, hemoglobin and the red blood cell number). Previously such conclusions were reached by (7).

Proudman and Wentworth (8) reported for a highly significant negative regression of egg production, associated with hematocrit levels in turkey breeder hens. According to the authors, the hematocrit levels might be a useful method for the rapid identification of a significant proportion of the unproductive hens in a turkey breeder flock. In a study on the changes in some blood parameters (hemoglobin, hematocrit, glucose and total protein) during the beginning, peak and end of the egg-laying period in Guinea fowls, (9) reported that the female birds had significantly increased hematocrit levels $(p<0,05)$, while other parameters had increased slightly. In the male birds, the hematocrit and hemoglobin levels were the highest before the peak of the laying period, and the glucose and the total protein were the highest before the peak and at the end of the laying period.

Bedrack et al. (10) observed no diurnal rhythm in the blood hematocrit levels, while there were different diurnal variations in circulating concentrations of gonadotropins, prolactin, corticosterone, estradiol, progesterone and testosterone in laying and broody White Rock domestic fowl.

Currently, there is a tendency in poultry farming to re-evaluate the genotypes and the rearing technologies used. The interest to dual purpose (eggs + meat) breeds suitable for a free range system or rearing in backyards Australorp, Sussex, Bielefelder, Faverolles, Wyandotte, etc., or attractive breeds laying Easter eggs with blue-green or chocolate shell color - Araucana, Ameraucana, Cream Legbar, Schijndelaar, Marans, etc., increased in the last years (11-13).

The aim of the present study was to compare some major hematological and biochemical blood parameters of 3 newly introduced poultry breeds - Australorp, Marans, and Araucana, during different stages of their egglaying period.

\section{MATERIAL AND METHODS}

The study was carried out on the poultry farm of the Agricultural University - Plovdiv with 3 introduced chicken breeds - Australorp (originating from Australia), Marans (originating from France), Araucana (originating from South America). Each group included 32 laying hens and 4 cocks, i.e. a sex ratio of $89: 1 \delta^{\lambda}$. All the birds were fed on the same diet and reared in a free range housing system, in equal conditions in sleeping pens and outdoor walking yards. The sleeping pens (size 3.50/2.50/2.75 m) were equipped with 3 perches, $2.50 \mathrm{~m}$ in length, and 8 two-floor wooden nest boxes of 30/30/40 cm each. The housing density of poultry in the sleeping houses was 3.93 birds per $1 \mathrm{~m}^{2}$ area.

Each group was provided with two tube feeders, placed under the eaves of the sleeping houses and with watering troughs ensuring feeding and drinking widths of 10 and $3 \mathrm{~cm}$ per bird, according to the requirements of (14). The fowls were watered and fed ad libitum. The birds received $140 \mathrm{~g}$ daily ration of combined feed given twice - in the morning and evening, with the following nutritional levels in $1 \mathrm{~kg}$ : Metabolizable Energy -11.8 MJ; Crude Protein $-17.3 \%$, Lysine $-0.81 \%$; Met.+Cystine - 0.73\%; Potassium - 3.63\%; Avail. Phosphorus $-0.36 \%$.

Blood samples were taken through the v. toracica lateralis from 4-6 female and 4 male specimens of each breed at 3 different laying stages - before the egg-laying peak (13.02.2019 - laying intensity of 13-20\%), during the egg-laying peak (10.05.2019 laying intensity of $57-80 \%$ ) and at the end of the egg-laying period (28.06.2019 - laying intensity of $25-32 \%$ ). Until the time of the test, the blood samples were stored in $3 \mathrm{ml}$ cuvettes with $3.2 \%$ sodium citrate (Vacuette) at a temperature of $4-8^{\circ} \mathrm{C}$. The operations were carried out in accordance with the requirements of environmental legislation (15). The following parameters were measured: total hemoglobin, hematocrit, glucose, total protein and total cholesterol levels.

The laying intensity (LI) was measured 2 days before and 2 days after the blood collection, using the formula:

LI = Total eggs for the day/number of layers*100

Total hemoglobin and hematocrit levels were measured using the Hemo Control Haematological analyser, EKF Diagnostic (Germany) and blood glucose was measured using Hemo Cue Glucose Analyser (Sweden). Protein content in blood plasma was determined through refractory using Clinical Refractometer ATC 4, following the method described by (16). 
The total cholesterol content in blood was measured spectrophotometrically using cholesterol total-L AMS tester of visible spectrophotometer V-1100 (JP Selecta).

\section{RESULTS AND DISCUSSION}

Table 1 presents the laying intensity established in the periods of blood collection. At the beginning of the laying period Araucana breed showed the lowest intensity, while in Australorp and Marans it was practically identical. During the next two stages Australop breed showed the highest laying intensity and the differences with the other 2 breeds were statistically significant. In the conditions of a free range housing system, Australorp breed showed the highest laying intensity for the whole laying period compared to the other investigated breeds. Marans breed showed the lowest intensity at the peak and at the end of the laying period, as well as during the whole laying season.

Table 1. Laying intensity of the different breeds, \%

\begin{tabular}{|c|c|c|c|}
\hline \multirow{3}{*}{ Breeds } & Beginning of laying & Peak of laying & End of laying \\
\cline { 2 - 4 } & $\mathrm{m} \pm$ SEM & $\mathrm{m} \pm$ SEM & $\mathrm{m} \pm$ SEM \\
\hline \multirow{2}{*}{ Australorp } & $19.87 \pm 0.75$ & $80.26 \pm 1.24$ & $32.27 \pm 1.91$ \\
& $\mathrm{a}_{1} \mathrm{a}_{2}$ & $\mathrm{~A}_{1} \mathrm{C}_{1} \mathrm{a}_{1} \mathrm{a}_{3}$ & $\mathrm{C}_{1} \mathrm{a}_{2} \mathrm{a}_{3}$ \\
\hline \multirow{2}{*}{ Marans } & $20.41 \pm 0.92$ & $57.99 \pm 1.41$ & $23.38 \pm 0,7$ \\
& $\mathrm{~A}_{1} \mathrm{a}_{1} \mathrm{a}_{2}$ & $\mathrm{~A}_{1} \mathrm{a}_{1} \mathrm{a}_{3}$ & $\mathrm{C}_{1} \mathrm{a}_{2} \mathrm{a}_{3}$ \\
\hline Araucana & $13.09 \pm 0,7$ & $66.11 \pm 3,16$ & $25.33 \pm 2,71$ \\
& $\mathrm{~A}_{1} \mathrm{a}_{1} \mathrm{~b}_{1}$ & $\mathrm{C}_{1} \mathrm{a}_{1} \mathrm{a}_{2}$ & $\mathrm{~b}_{1} \mathrm{a}_{2}$ \\
\hline
\end{tabular}

Note: The difference is significant at: $\mathrm{P}<0,001-\mathrm{a}_{1}-\mathrm{a}_{1} \ldots \mathrm{a}_{3}-\mathrm{a}_{3} ; \mathrm{P}<0,01-\mathrm{b}_{1}-\mathrm{b}_{1} \ldots \mathrm{b}_{2}-\mathrm{b}_{2} ; \mathrm{P}<0,05-\mathrm{c}_{1}-\mathrm{c}_{1} \ldots \mathrm{c}_{4}-\mathrm{c}_{4}$ in the same row; $\mathrm{P}<0,001-\mathrm{A}_{1}-\mathrm{A}_{1} ; \mathrm{P}<0,05-\mathrm{C}_{1}-\mathrm{C}_{1}$ in the same column.

Compared to the hens, the hemoglobin level was higher in the cocks of the three breeds during all the studied periods, with an exception of Marans at the peak of laying (Table 2). In most periods, Australorp birds had higher values compared to the two other breeds. The differences in most comparisons were statistically significant. It can be concluded that the higher hemoglobin levels in Australorp hens correlated positively with their higher seasonal laying intensity.

Table 2. Hemoglobin content during the tested periods, $g * d l^{-1}$

\begin{tabular}{|c|c|c|c|c|c|c|}
\hline \multirow[b]{2}{*}{ Breeds } & \multicolumn{2}{|c|}{ Beginning of laying } & \multicolumn{2}{|c|}{ Peak of laying } & \multicolumn{2}{|c|}{ End of laying } \\
\hline & $\begin{array}{c}\text { Male } \\
\mathrm{m} \pm \text { SEM }\end{array}$ & $\begin{array}{l}\text { Female } \\
\mathrm{m} \pm \text { SEM }\end{array}$ & $\begin{array}{c}\text { Male } \\
\mathrm{m} \pm \text { SEM }\end{array}$ & $\begin{array}{l}\text { Female } \\
\mathrm{m} \pm \text { SEM }\end{array}$ & $\begin{array}{c}\text { Male } \\
\mathrm{m} \pm \text { SEM }\end{array}$ & $\begin{array}{c}\text { Female } \\
\mathrm{m} \pm \text { SEM }\end{array}$ \\
\hline Australorp & $\begin{array}{c}12.98 \pm 0.23 \\
\mathrm{~A}_{1} \mathrm{C}_{1} \mathrm{a}_{1} \mathrm{a}_{2} \mathrm{a}_{3} \mathrm{~b}_{1}\end{array}$ & $\begin{array}{l}10.42 \pm 0.18 \\
A_{1} B_{1} a_{1} a_{4} b_{2} b_{3} \\
b_{4}\end{array}$ & $\begin{array}{c}11.37 \pm 0.14 \\
\mathrm{~A}_{1} \mathrm{C}_{1} \mathrm{a}_{2} \mathrm{a}_{5} \mathrm{a}_{6} \mathrm{~b}_{2}\end{array}$ & $\begin{array}{c}9.38 \pm 0.08 \\
C_{1} a_{3} a_{5} a_{7} a_{8} \\
b_{3}\end{array}$ & $\begin{array}{c}13.40 \pm 0.24 \\
\mathrm{a}_{4} \mathrm{a}_{6} \mathrm{a}_{7} \mathrm{a}_{9}\end{array}$ & $\begin{array}{c}11.60 \pm 0.12 \\
\mathrm{~A}_{1} \mathrm{~A}_{2} \mathrm{a}_{8} \mathrm{a}_{9} \mathrm{~b}_{1} \mathrm{~b}_{4}\end{array}$ \\
\hline Marans & $\begin{array}{c}11.28 \pm 0.08 \\
\mathrm{~A}_{1} \mathrm{~A}_{2} \mathrm{a}_{1} \mathrm{a}_{2} \mathrm{a}_{3} \\
\mathrm{a}_{4} \mathrm{~b}_{1}\end{array}$ & $\begin{array}{c}7.98 \pm 0.07 \\
\mathrm{~A}_{1} \mathrm{~A}_{2} \mathrm{a}_{1} \mathrm{a}_{5}\end{array}$ & $\begin{array}{c}8.38 \pm 0.17 \\
\mathrm{~A}_{1} \mathrm{~A}_{2} \mathrm{a}_{2} \mathrm{a}_{6}\end{array}$ & $\begin{array}{c}9.02 \pm 0.5 \\
b_{1} a_{7}\end{array}$ & $\begin{array}{c}13.45 \pm 0.21 \\
\mathrm{a}_{3} \mathrm{a}_{5} \mathrm{a}_{6} \mathrm{a}_{7} \mathrm{a}_{8}\end{array}$ & $\begin{array}{c}7.30 \pm 0.71 \\
\mathrm{~A}_{1} \mathrm{C}_{1} \mathrm{a}_{4} \mathrm{a}_{8}\end{array}$ \\
\hline Araucana & $\begin{array}{c}13.65 \pm 0.07 \\
\mathrm{~A}_{2} \mathrm{C}_{1} \mathrm{a}_{1} \mathrm{a}_{2} \mathrm{a}_{3} \mathrm{a}_{4}\end{array}$ & $\begin{array}{r}9.40 \pm 0.06 \\
\mathrm{~A}_{2} \mathrm{~B}_{1} \mathrm{a}_{1} \mathrm{a}_{5} \mathrm{a}_{6} \mathrm{c}_{1}\end{array}$ & $\begin{array}{l}10.90 \pm 0.07 \\
\mathrm{~A}_{1} \mathrm{C}_{1} \mathrm{a}_{2} \mathrm{a}_{5} \mathrm{a}_{7} \mathrm{a}_{8} \mathrm{a}_{9}\end{array}$ & $\begin{array}{l}9.08 \pm 0.07 \\
C_{1} a_{3} a_{7} a_{10} c_{1}\end{array}$ & $\begin{array}{c}13.55 \pm 0.25 \\
\mathrm{a}_{6} \mathrm{a}_{8} \mathrm{a}_{10} \mathrm{a}_{11}\end{array}$ & $\begin{array}{c}9.17 \pm 0.1 \\
\mathrm{~A}_{2} \mathrm{C}_{1} \mathrm{a}_{4} \mathrm{a}_{9} \mathrm{a}_{11}\end{array}$ \\
\hline
\end{tabular}

Note: The difference is significant at: $P<0,001-a_{1}-a_{1} \ldots a_{11}-a_{11} ; P<0,01-b_{1}-b_{1} \ldots b_{4}-b_{4} ; P<0,05-c_{1}-c_{1}$ in the same row; $\mathrm{P}<0,001-\mathrm{A}_{1}-\mathrm{A}_{1}-\mathrm{A}_{2}-\mathrm{A}_{2} ; \mathrm{P}<0,01-\mathrm{B}_{1}-\mathrm{B}_{1} ; \mathrm{P}<0,05-\mathrm{C}_{1}-\mathrm{C}_{1}$ in the same column:

It should be noted that there were differences in the variation of that parameter in the three breeds. Thus, an Australorp, the hemoglobin concentration in the blood of the female birds decreased during the laying peak and after its end it increased again and even exceeded the level reported before the beginning of egglaying. In Marans breed, the tendency was the opposite (levels increased during the peak), whereas in Araucana it did not change significantly during the studied period. Thus, it can be concluded that the breed had a significant effect on the hemoglobin synthesis balance and its degradation in female birds. Changes in the hemoglobin values were identical in the cocks of all the three breeds - a decrease during the peak of egg-laying and recovery of the values after the end of that 
period. Differences regarding the variation in the hemoglobin content in the blood of laying bird species were also found in the literature. In our previous studies, we established that the hemoglobin content in the blood of laying guinea-fowl increased during the egg-laying peak (9), while in pheasants (Phasianus colchicus) the hemoglobin content decreased during the egg-laying peak (17).

The established by us results for the hemoglobin content for the three races are very close to data, cited from (18) - 10.2-15.1 (mean $\left.12.6 \mathrm{~g}^{*} \mathrm{dl}^{-1}\right),(19)-11-13 \mathrm{~g}^{*} \mathrm{dl}^{-1}$ and (20) for broiler chickens $-11,4 \mathrm{~g}^{*} \mathrm{dl}^{-1}$. Other publications (Avian hematology) show lower referent values for the hemoglobin content of layers $-9.3 \mathrm{~g}^{*} \mathrm{dl}^{-1}$.

Monitoring the hematocrit levels (Table 3) showed almost the same tendencies as hemoglobin content. With the exception of Marans at the peak of the laying period, the cocks had significantly higher levels than the hens in all the three breeds. The lowest values were established in the males of all the three breeds at the peak of laying, while no significant variations were observed in the hens, with the exception of Australorp at the beginning of the laying period.

Table 3. Hematocrit content during the tested periods, \%

\begin{tabular}{|c|c|c|c|c|c|c|}
\hline \multirow{3}{*}{ Breeds } & \multicolumn{2}{|c|}{ Beginning of laying } & \multicolumn{2}{c|}{ Peak of laying } & \multicolumn{2}{c|}{ End of laying } \\
\cline { 2 - 7 } & $\begin{array}{c}\text { Male } \\
\text { m } \pm \text { SEM }\end{array}$ & $\begin{array}{c}\text { Female } \\
\text { m } \pm \text { SEM }\end{array}$ & $\begin{array}{c}\text { Male } \\
\text { m } \pm \text { SEM }\end{array}$ & $\begin{array}{c}\text { Female } \\
\text { m } \pm \text { SEM }\end{array}$ & $\begin{array}{c}\text { Male } \\
\text { m } \pm \text { SEM }\end{array}$ & $\begin{array}{c}\text { Female } \\
\text { m } \pm \text { SEM }\end{array}$ \\
\hline \multirow{2}{*}{ Australorp } & $40.88 \pm 0.49$ & $30.48 \pm 0.61$ & $33.03 \pm 0.46$ & $27.50 \pm 0.46$ & $35.40 \pm 0.25$ & $26.27 \pm 1.30$ \\
& $\mathrm{~A}_{1} \mathrm{a}_{1} \mathrm{a}_{2} \mathrm{a}_{3} \mathrm{a}_{4} \mathrm{a}_{5}$ & $\mathrm{~A}_{1} \mathrm{a}_{1} \mathrm{a}_{6} \mathrm{~b}_{1} \mathrm{c}_{1} \mathrm{c}_{2}$ & $\mathrm{~B}_{1} \mathrm{a}_{2} \mathrm{a}_{7} \mathrm{~b}_{2} \mathrm{~b}_{3} \mathrm{c}_{1}$ & $\mathrm{a}_{3} \mathrm{a}_{7} \mathrm{a}_{8} \mathrm{~b}_{1}$ & $\mathrm{C}_{1} \mathrm{a}_{4} \mathrm{a}_{6} \mathrm{a}_{8} \mathrm{a}_{9} \mathrm{~b}_{2}$ & $\mathrm{a}_{5} \mathrm{a}_{9} \mathrm{~b}_{3} \mathrm{c}_{2}$ \\
\hline \multirow{2}{*}{ Marans } & $31.97 \pm 1.22$ & $23.72 \pm 0.29$ & $23.16 \pm 1.60$ & $25.61 \pm 2.16$ & $32.07 \pm 1.21$ & $25.86 \pm 1.21$ \\
& $\mathrm{~A}_{1} \mathrm{C}_{1} \mathrm{a}_{1} \mathrm{~b}_{1} \mathrm{c}_{1} \mathrm{c}_{2}$ & $\mathrm{~A}_{1} \mathrm{~A}_{2} \mathrm{a}_{1} \mathrm{a}_{2}$ & $\mathrm{C}_{1} \mathrm{~b}_{1}$ & $\mathrm{c}_{1} \mathrm{c}_{3}$ & $\mathrm{C}_{1} \mathrm{a}_{2} \mathrm{c}_{3} \mathrm{c}_{4}$ & $\mathrm{c}_{2} \mathrm{c}_{4}$ \\
\hline \multirow{2}{*}{ Araucana } & $38.37 \pm 1.95$ & $28.49 \pm 0.56$ & $33.33 \pm 3.47$ & $25.67 \pm 1.14$ & $36.90 \pm 4.29$ & $\begin{array}{c}27.40 \pm 1.61 \\
\end{array}$ \\
\cline { 2 - 7 } & $\mathrm{C}_{1} \mathrm{~b}_{1} \mathrm{~b}_{2} \mathrm{~b}_{3}$ & $\mathrm{~A}_{2} \mathrm{~b}_{1}$ & $\mathrm{~B}_{1} \mathrm{C}_{1}$ & $\mathrm{~b}_{2} \mathrm{c}_{1}$ & $\mathrm{c}_{1}$ & $\mathrm{~b}_{3}$ \\
\hline
\end{tabular}

Note: The difference are significant at: $\mathrm{P}<0,001-\mathrm{a}_{1}-\mathrm{a}_{1} \ldots \mathrm{a}_{9}-\mathrm{a}_{9} ; \mathrm{P}<0,01-\mathrm{b}_{1}-\mathrm{b}_{1} \ldots \mathrm{b}_{3}-\mathrm{b}_{3} ; \mathrm{P}<0,05-\mathrm{c}_{1}-\mathrm{c}_{1} \ldots \mathrm{c}_{4}-\mathrm{c}_{4}$ in the same row; $\mathrm{P}<0,001-\mathrm{A}_{1}-\mathrm{A}_{1} \ldots \mathrm{A}_{2}-\mathrm{A}_{2} ; \mathrm{P}<0,01-\mathrm{B}_{1}-\mathrm{B}_{1} ; \mathrm{P}<0,05-\mathrm{C}_{1}-\mathrm{C}_{1}$ in the same column:

Our results are comparable with these, cited by (2) for laying hens (25-30\%), (20) for broiler chickens $-33-35 \%$, so as by (18), who reports, that those index is normally very variable from 30 to 49 (mean 39.5)\%.

In the present study, similar to the hemoglobin content, the three breeds showed differences in the parameter variations during the experiment. In literature, there were also differences in hematocrit changes, found in some bird species during the egg-laying season $(9,17)$. According to $(6,7,21)$ the hemoglobin and hematocrit contents in the female birds decrease to the degree of anemia by intensive laying. Decreased hematocrit, red blood cell counts, and hemoglobin concentration did not recover at clutch completion, but showed evidence of recovery to baseline pre-breeding levels at hatching. The decrease is proportional to the egg laying effort. Opposite, the hematocrit increasing is a part of the adaptive reactions to lower temperature, while the diet type doesn't influence the anemia's manifesting (21). Probably, the hematocrit changes in our experiment are a result of the combined influence of 2 factors - laying intensity and adaptation of new introduced races to the (South) Bulgarian environmental conditions. For the three investigated breeds it wasn't established anemia, while for Maran breed it was established increasing of the studied index, which could be explained with the lowest laying intensity, compared to other races, respectively with the lowest egg laying effort.

The blood glucose content is an indicator of the adequate supply of energy to the cells. Higher blood glucose values, combined with high hemoglobin values, are a prerequisite for the better energy supply at the cellular level. At the high physical activity of the body, the blood glucose content can decrease to a certain extent, and in order to compensate for it, the glucose intake must be increased by a proper diet. Data obtained in the present study show (Table 4) that in hens, the highest values were reported in Araucana breed at the beginning and peak of laying, the differences being significant. At the end of lying, the blood glucose was relatively low, with no statistically significant differences between the breeds. The males exhibited higher and more reliable 
variation between the breeds, the lowest values being established in Australorp in all the three studied periods. In general, hens of all the breeds had higher values of the parameter compared to cocks, which corresponded to the higher energy metabolism in their body due to the egg-laying activity.

Table 4. Glucose content during the tested periods, $\mathrm{mmol}^{*} l^{-1}$

\begin{tabular}{|c|c|c|c|c|c|c|}
\hline \multirow{3}{*}{ Breeds } & \multicolumn{2}{|c|}{ Beginning of laying } & \multicolumn{2}{c|}{ Peak of laying } & \multicolumn{2}{c|}{ End of laying } \\
\cline { 2 - 7 } & Male & Female & Male & Female & Male & Female \\
& $\mathrm{m} \pm$ SEM & m \pm SEM & m \pm SEM & m \pm SEM & m \pm SEM & m \pm SEM \\
\hline \multirow{2}{*}{ Australorp } & $6.10 \pm 0.05$ & $7.08 \pm 0.07$ & $7.25 \pm 0.07$ & $7.43 \pm 0.13$ & $6.23 \pm 0.1$ & $6.90 \pm 0.09$ \\
& $\mathrm{~A}_{1} \mathrm{~A}_{2} \mathrm{a}_{1} \mathrm{a}_{2} \mathrm{a}_{3} \mathrm{a}_{4}$ & $\mathrm{~A}_{1} \mathrm{~A}_{2} \mathrm{a}_{1} \mathrm{a}_{5}$ & $\mathrm{~A}_{1} \mathrm{a}_{2} \mathrm{a}_{6} \mathrm{c}_{1}$ & $\mathrm{~A}_{1} \mathrm{a}_{3} \mathrm{a}_{7} \mathrm{c}_{2}$ & $\mathrm{~A}_{1} \mathrm{a}_{5} \mathrm{a}_{6} \mathrm{a}_{7} \mathrm{~b}_{1}$ & $\mathrm{a}_{4} \mathrm{~b}_{1} \mathrm{c}_{1} \mathrm{c}_{2}$ \\
\hline \multirow{2}{*}{ Marans } & $9.30 \pm 0.24$ & $6.42 \pm 0.07 \mathrm{~A}_{1}$ & $7.20 \pm 0.11$ & $8.40 \pm 0.47$ & $8.15 \pm 0.07$ & $7.00 \pm 0.12$ \\
& $\mathrm{~A}_{1} \mathrm{a}_{1} \mathrm{a}_{2} \mathrm{~b}_{1} \mathrm{a}_{3}$ & $\mathrm{~A}_{3} \mathrm{a}_{1} \mathrm{a}_{4} \mathrm{a}_{5} \mathrm{~b}_{2} \mathrm{~b}_{3}$ & $\mathrm{~A}_{2} \mathrm{a}_{2} \mathrm{a}_{4} \mathrm{a}_{6} \mathrm{c}_{1}$ & $\mathrm{~B}_{1} \mathrm{~b}_{2} \mathrm{c}_{1} \mathrm{c}_{2}$ & $\mathrm{~A}_{1} \mathrm{~A}_{2} \mathrm{a}_{5} \mathrm{a}_{6} \mathrm{a}_{7} \mathrm{~b}_{1}$ & $\mathrm{a}_{3} \mathrm{a}_{7} \mathrm{~b}_{3} \mathrm{c}_{2}$ \\
\hline \multirow{2}{*}{ Araucana } & $9.85 \pm 0.07$ & $10.67 \pm 0.13$ & $9.93 \pm 0.16$ & $10.87 \pm 0.30$ & $6.47 \pm 0.11$ & $6.32 \pm 0.56$ \\
& $\mathrm{~A}_{2} \mathrm{a}_{1} \mathrm{a}_{2} \mathrm{~b}_{1} \mathrm{c}_{1}$ & $\mathrm{~A}_{2} \mathrm{~A}_{3} \mathrm{a}_{3} \mathrm{a}_{4} \mathrm{~b}_{1} \mathrm{c}_{2}$ & $\mathrm{~A}_{1} \mathrm{~A}_{2} \mathrm{a}_{5} \mathrm{a}_{6} \mathrm{c}_{2} \mathrm{c}_{3}$ & $\mathrm{~A}_{1} \mathrm{~B}_{1} \mathrm{a}_{7} \mathrm{a}_{8} \mathrm{c}_{1} \mathrm{c}_{3}$ & $\mathrm{~A}_{1} \mathrm{a}_{1} \mathrm{a}_{3} \mathrm{a}_{5} \mathrm{a}_{7}$ & $\mathrm{a}_{2} \mathrm{a}_{4} \mathrm{a}_{6} \mathrm{a}_{8}$ \\
\hline
\end{tabular}

Note: The difference are significant at: $\mathrm{P}<0,001-\mathrm{a}_{1}-\mathrm{a}_{1} \ldots \mathrm{a}_{8}-\mathrm{a}_{8} ; \mathrm{P}<0,01-\mathrm{b}_{1}-\mathrm{b}_{1} \ldots \mathrm{b}_{3}-\mathrm{b}_{3} ; \mathrm{P}<0,05-\mathrm{c}_{1}-\mathrm{c}_{1} \ldots \mathrm{c}_{3}-\mathrm{c}_{3}$ in the same row; $\mathrm{P}<0,001-\mathrm{A}_{1}-\mathrm{A}_{1} \ldots \mathrm{A}_{3}-\mathrm{A}_{3} ; \mathrm{P}<0,01-\mathrm{B}_{1}-\mathrm{B}_{1}$ in the same column

According Avian hematology (30) the established by us results are within the physiological limits $\left(7-11.3 \mathrm{mmol}^{* l^{-1}}\right)$, but they are a little lower, compared to other authors - $(2,22-24)$ who report levels from $10.6-13.8 \mathrm{mmol}^{*} \mathrm{l}^{-1}$.

In our preliminary investigation with Guinea fowls, it was established that during the laying period the glucose content in the male's and female's blood varies (9). In this investigation, we didn't establish a high dynamic in the glucose contents.

Eggs are a product rich in protein and amino acids. In that aspect, maintaining a normal total protein level in blood is of most importance for the high laying performance. The data in Table 5 show that the hens of the breed having the best egg production performance (Australorp) also had the highest total protein levels at the beginning and end of laying, as at the peak of laying the level of blood protein decreases. The differences were statistically significant. In the lowest productive breed, the total protein levels were high during the three periods, and, in Araucana, the values of the parameter were intermediate and relatively similar during the separate periods. The cocks of all the three breeds had lower or identical to the hen values, the lowest one in comparison with that of the hens being reported in Marans at the peak of laying.

Table 5. Total protein content in blood during the tested periods, $g * d l^{-1}$

\begin{tabular}{|c|c|c|c|c|c|c|}
\hline \multirow{3}{*}{ Breeds } & \multicolumn{2}{|c|}{ Start of laying } & \multicolumn{2}{c|}{ Peak of laying } & \multicolumn{2}{c|}{ End of laying } \\
\cline { 2 - 7 } & Male & Female & Male & Female & Male & Female \\
& $\mathrm{m} \pm$ SEM & $\mathrm{m} \pm$ SEM & $\mathrm{m} \pm$ SEM & $\mathrm{m} \pm$ SEM & $\mathrm{m} \pm$ SEM & $\mathrm{m} \pm$ SEM \\
\hline \multirow{2}{*}{ Australorp } & $5.93 \pm 0.64$ & $8.46 \pm 0.13$ & $5.33 \pm 0.43$ & $5.77 \pm 0.21$ & $6.90 \pm 0.25$ & $7.87 \pm 0.12 \mathrm{~A}_{1}$ \\
& $\mathrm{~B}_{1} \mathrm{~b}_{1} \mathrm{c}_{1}$ & $\mathrm{~A}_{1} \mathrm{a}_{1} \mathrm{a}_{2} \mathrm{~b}_{1} \mathrm{~b}_{2} \mathrm{c}_{2}$ & $\mathrm{C}_{1} \mathrm{a}_{1} \mathrm{~b}_{3} \mathrm{c}_{3}$ & $\mathrm{~B}_{1} \mathrm{C}_{1} \mathrm{a}_{2} \mathrm{a}_{3} \mathrm{c}_{4}$ & $\mathrm{~b}_{2} \mathrm{c}_{3} \mathrm{c}_{4} \mathrm{c}_{5}$ & $\mathrm{~B}_{1} \mathrm{a}_{3} \mathrm{a}_{5} \mathrm{~b}_{3} \mathrm{c}_{1} \mathrm{c}_{2}$ \\
\hline \multirow{2}{*}{ Marans } & $7.70 \pm 0.07$ & $8.43 \pm 0.23$ & $4.40 \pm 0.14$ & $8.73 \pm 0.54$ & $6.40 \pm 0.07$ & $6.33 \pm 0.18$ \\
& $\mathrm{~A}_{1} \mathrm{~B}_{1} \mathrm{a}_{1} \mathrm{a}_{2} \mathrm{a}_{3}$ & $\mathrm{~A}_{2} \mathrm{a}_{4} \mathrm{a}_{5} \mathrm{a}_{6}$ & $\mathrm{~A}_{1} \mathrm{a}_{1} \mathrm{a}_{4} \mathrm{a}_{7} \mathrm{a}_{8} \mathrm{a}_{9}$ & $\mathrm{~B}_{1} \mathrm{C}_{2} \mathrm{a}_{7} \mathrm{~b}_{1} \mathrm{~b}_{2}$ & $\mathrm{a}_{2} \mathrm{a}_{5} \mathrm{a}_{8} \mathrm{~b}_{1}$ & $\mathrm{~A}_{1} \mathrm{a}_{3} \mathrm{a}_{6} \mathrm{a}_{9} \mathrm{~b}_{2}$ \\
\hline \multirow{2}{*}{ Araucana } & $6.00 \pm 0.14$ & $5.97 \pm 0.22$ & $7.97 \pm 0.39 \mathrm{~A}_{1}$ & $6.68 \pm 0.26$ & $6.27 \pm 0.08$ & $6.60 \pm 0.18$ \\
& $\mathrm{~A}_{1} \mathrm{~b}_{1} \mathrm{c}_{1}$ & $\mathrm{~A}_{1} \mathrm{~A}_{2} \mathrm{~b}_{2}$ & $\mathrm{C}_{1} \mathrm{~b}_{1} \mathrm{~b}_{2} \mathrm{~b}_{3} \mathrm{c}_{2} \mathrm{c}_{3}$ & $\mathrm{C}_{1} \mathrm{C}_{2} \mathrm{c}_{2}$ & $\mathrm{~b}_{3}$ & $\mathrm{~B}_{1} \mathrm{c}_{1} \mathrm{c}_{3}$ \\
\hline
\end{tabular}

Note: The difference are significant at: $\mathrm{P}<0,001-\mathrm{a}_{1}-\mathrm{a}_{1} \ldots \mathrm{a}_{9}-\mathrm{a}_{9} ; \mathrm{P}<0,01-\mathrm{b}_{1}-\mathrm{b}_{1} \ldots \mathrm{b}_{3}-\mathrm{b}_{3} ; \mathrm{P}<0,05-\mathrm{c}_{1}-\mathrm{c}_{1} \ldots \mathrm{c}_{4}-\mathrm{c}_{4}$ in the same row; $\mathrm{P}<0,001-\mathrm{A}_{1}-\mathrm{A}_{1}-\mathrm{A}_{2}-\mathrm{A}_{2} ; \mathrm{P}<0,01-\mathrm{B}_{1}-\mathrm{B}_{1} ; \mathrm{P}<0,05-\mathrm{C}_{1}-\mathrm{C}_{1}-\mathrm{C}_{2}-\mathrm{C}_{2}$ in the same column:

Total protein values of female and male Marans and female Australorp, established in the present study, were higher than most published in the scientific literature for eggtype poultry breeds $(2,20,22-27)$. Our results were closest to the total protein values of laying hens fed on raw Anthonotha macrophylla seed meal, reported by (19). The probable reason for the variation of the total protein parameter in the present study, as well as in data published by other authors, is that the protein intake from the feed is more than the amount required for the maintenance of life and for egg production.

Trakia Journal of Sciences, Vol. 18, Suppl. 1, 2020 
According(25 and 30), the total protein in female's blood increases during the intensive laying. In our investigation such kind of increasing is observed only for Araucana breed, while for the other 2 races the trend is opposite.
Blood cholesterol levels in the males (Table 6) were quite similar over the three studied periods, with the highest values being reported in Australorp - between 3.39 and 3.74 mmol*1. The differences with the cocks of the other two breeds (Marans - between 2.36 and 2.91 and Araucana - between 2.05 and 2.58) were significant.

Table 6. Total cholesterol content during the tested periods, mmol $*^{-1}$

\begin{tabular}{|c|c|c|c|c|c|c|}
\hline \multirow{3}{*}{ Breeds } & \multicolumn{2}{|c|}{ Start of laying } & \multicolumn{2}{c|}{ Peak of laying } & \multicolumn{2}{c|}{ End of laying } \\
\cline { 2 - 7 } & Male & Female & Male & Female & Male & Female \\
& $\mathrm{m} \pm$ SEM & $\mathrm{m} \pm$ SEM & $\mathrm{m} \pm$ SEM & $\mathrm{m} \pm$ SEM & m \pm SEM & \begin{tabular}{c} 
m \pm SEM \\
\hline \multirow{2}{*}{ Australorp }
\end{tabular} \\
& $3.39 \pm 0.05$ & $2.81 \pm 0.04$ & $3.49 \pm 0.08$ & $3.74 \pm 0.27$ & $3.71 \pm 0,69$ & $1.92 \pm 0,18 \mathrm{~B}_{1}$ \\
& $\mathrm{~A}_{1} \mathrm{C}_{1} \mathrm{a}_{1} \mathrm{a}_{2}$ & $\mathrm{~B}_{1} \mathrm{a}_{1} \mathrm{a}_{3} \mathrm{~b}_{1} \mathrm{c}_{1}$ & $\mathrm{~A}_{1} \mathrm{a}_{3} \mathrm{a}_{4}$ & $\mathrm{C}_{1} \mathrm{C}_{2} \mathrm{~b}_{2} \mathrm{c}_{1}$ & $\mathrm{c}_{2}$ & $\mathrm{C}_{1} \mathrm{a}_{2} \mathrm{a}_{4} \mathrm{~b}_{1} \mathrm{~b}_{2} \mathrm{c}_{2}$ \\
\hline \multirow{2}{*}{ Marans } & $2.77 \pm 0.19$ & $4.11 \pm 0.27$ & $2.91 \pm 0.23$ & $2.74 \pm 0.25$ & $2.36 \pm 0.11$ & $4.74 \pm 0.52$ \\
& $\mathrm{C}_{1} \mathrm{C}_{2} \mathrm{~b}_{1} \mathrm{c}_{1}$ & $\mathrm{~B}_{1} \mathrm{a}_{1} \mathrm{~b}_{1} \mathrm{~b}_{2} \mathrm{c}_{2}$ & $\mathrm{c}_{2} \mathrm{c}_{3}$ & $\mathrm{~A}_{1} \mathrm{C}_{1} \mathrm{~b}_{2} \mathrm{c}_{4}$ & $\mathrm{~b}_{3}$ & $\mathrm{~B}_{1} \mathrm{a}_{1} \mathrm{~b}_{3} \mathrm{c}_{1} \mathrm{c}_{3} \mathrm{c}_{4}$ \\
\hline \multirow{2}{*}{ Araucana } & $2.05 \pm 0.13$ & $2.58 \pm 0.40$ & $2.44 \pm 0.09$ & $6.57 \pm 0.74$ & $2.58 \pm 0.22$ & $4.38 \pm 0.73$ \\
& $\mathrm{~A}_{1} \mathrm{C}_{2} \mathrm{a}_{1} \mathrm{c}_{1}$ & $\mathrm{~b}_{1}$ & $\mathrm{~A}_{1} \mathrm{~b}_{2} \mathrm{c}_{2}$ & $\mathrm{~A}_{1} \mathrm{C}_{2} \mathrm{a}_{1} \mathrm{~b}_{1} \mathrm{~b}_{2} \mathrm{~b}_{3}$ & $\mathrm{~b}_{3}$ & $\mathrm{C}_{1} \mathrm{c}_{1} \mathrm{c}_{2}$ \\
\hline
\end{tabular}

Note: The difference are significant at: $\mathrm{P}<0,001-\mathrm{a}_{1}-\mathrm{a}_{1} \ldots \mathrm{a}_{3}-\mathrm{a}_{3} ; \mathrm{P}<0,01-\mathrm{b}_{1}-\mathrm{b}_{1} \ldots \mathrm{b}_{2}-\mathrm{b}_{2} ; \mathrm{P}<0,05-\mathrm{c}_{1}-\mathrm{c}_{1} \ldots \mathrm{c}_{4}-\mathrm{c}_{4}$ in the same row; $\mathrm{P}<0,001-\mathrm{A}_{1}-\mathrm{A}_{1} ; \mathrm{P}<0,01-\mathrm{B}_{1}-\mathrm{B}_{1} ; \mathrm{P}<0,05-\mathrm{C}_{1}-\mathrm{C}_{1}-\mathrm{C}_{2}-\mathrm{C}_{2}$ in the same column:

No significant dependencies were observed in layers either between the studied breeds or between the periods of laying intensity. The highest variation was reported in Araucana breed - from 2.58 to 6.57 and the lowest in Australorp - from 2.81 to $3.74 \mathrm{mmol}^{*} \mathrm{l}-1$.

Our results are close to these, cited by (28) for laying hens (3.99- $\left.4.83 \mathrm{mmol}^{*} \mathrm{l}^{-1}\right)$ and $(2,22$, $23,24,25,29)$ for layers in different ages between 2.49 and $6.18 \mathrm{mmol}^{* \mathrm{l}^{-1}}$.

The dynamics of the parameter's change in the laying hens is partly confirmed by (25), who report that the total cholesterol increases in the laying period. The differences under the investigated breeds could be explained with the different degrees of adaptation to the environmental conditions, especially to the higher protein diet, especially to the lower laying intensity breeds Marans and Araucana.

\section{CONCLUSIONS}

In the conditions of a free range housing system, the highest laying intensity for the whole laying period was established in Australorp breed - from 20\% (beginning of the laying period) and $80 \%$ (peak of laying). The other two breeds showed significantly lower laying intensity - from 20\% to 60\% (Marans) and from $13 \%$ to $66 \%$ (Araucana), respectively.

The cocks of all the three breeds had higher hemoglobin content in blood than the hens, the differences in the breeds Marans and Araucana being significant. The hematocrit content was identical with the hemoglobin content, except for Marans breed at the peak of laying, when it was slightly higher in the layers compared to the cocks.

The hens of all the three studied breeds had a higher blood glucose content at the egg-laying peak than the cocks, corresponding to their higher energy consumption.

Both the cocks and the hens of the three breeds showed higher total protein content in blood at the beginning and end of the laying period, while at the peak of laying the values, especially in the layers, were lower. That was probably due to the high protein level in the feed $(17.5 \%)$, which was higher than the requirements of hens even when reaching over $90 \%$ laying intensity.

The variations in the investigated hematological and biochemical parameters in the blood of the three races are a result of the simultaneous effect of several factors - breed genetic differences, differences in egg laying effort, degree of adaptation to climatic conditions in (South) Bulgaria and the diet.

\section{REFERENCES}

1. Pandian, C., Pandiyan, M. T., Sundaresan, A.\& Omprakash, A. V. Haematological profile and erythrocyte indices in different 
breeds of poultry. Int. J. Livest. Res., 2(3), 89-92, 2012.

2. Cerolini, S., Baldi, A., Cavalchini, L. G., Blood and plasma biochemical variables in laying hens of different strains and ages. AGE (w K), 3, 5, 1990.

3. Gerzilov, V., Nikolov, A., Petrov, P., Bozakova, N., Penchev, G., Bochukov A., Effect of a dietary herbal mixture supplement on the growth performance, egg production and health status in chickens. J. of Centr. European Agriculture, 16, 2:10-27, 2015

4. Straková, E., Suchý, P., Kábelová, R., Vitula, F., Herzig, I. Values of Selected Haematological Indicators in Six Species of Feathered Game. Act. Vet. Brno, 1, 3: 5156, 2010.

5. Williams, T. D. Mechanisms underlying the costs of egg production. Bio Science, 55 (1), 39-48, 2005.

6. Campbell, T. W., Ellis, C., Avian and Exotic Animal Hematology and Cytology, 3rd edn. Ames: Iowa State Press, 2007.

7. Williams, T. D., Challenger, W., Christians, J., Evanson, M., Love, O, Vezina, F. What causes the decrease in hematocrit during egg production? Functional Ecology, 18, 330-336, 2004.

8. Proudman, J. A., Wentworth, B. C. Hematocrit as an indicator of egg production in turkey breeder hens. Poultry Science, 56(3), 807-809, 1977.

9. Penkov D., Arnaudov A.,Nikolova, M. Dynamics of some basic blood indices in guinea fowl (N. meleagris) depending on the egg laying period. Trakia Journal of Sciences, 4, 323-328,2019.

10. Bedrak, E., Harvey S., Chadwick, A., Concentrations of pituitary, gonadal and adrenal hormones in serum of laying and broody white rock hens (Gallus domesticus). Journal of Endocrinology, 89(2), 197-204, 1981, DOI: https://doi.org/10.1677/joe.0.0890197

11. Lukanov, H., Blue-green coloured eggs in Gallus gallus domesticus. Agricultural Science and Technology, 6 (1), 3-10, 2014.

12. Lukanov, H., Petrov, P., Genchev, A., Halil E., Ismail, N. Productive performance of Easter egger crosses of Araucana and Schijndelaar roosters with White leghorn hens. Trakia Journal of Sciences, 14(1), 72$79,2015$.

https://doi:10.15547/tjs.2016.01.010 .
13. Lukanov, H.,Petrov P., Gerzilov, V. Chicken eggs in blue-green color of the egg shell - a mystery to modern science. Journal of Animal Science, 36 (3), 80-85 (Bg), 2012.

14. Regulation No 15/2006 of 3 February 2006 on the minimum requirements for the protection and welfare of experimental animals and requirements to establishments, growing and/or supply, State Gazette No 17 (Bg), 2006.

15. Regulation No 44/2006 of 24 April 2006 for veterinary medical requirements of animal rearing facilities. State Gazette No $41(\mathrm{Bg}), 2006$.

16. Andreasen, C. B., Latimer, K. S., Kircher, I. M., Brown, J., Determination of chicken and turkey plasma and serum protein concentrations by refractometry and the biuret method. Avian Dis., 33: 93-96, 1989.

17. Hrabcakova, P., Voslarova, E., Bedanova, I., Pistekova, V., Chloupek, J., Changes in selected haematological and biochemical parameters in debeaked pheasant hens during the laying period. Ankara Üniversitesi Veteriner Fakültesi Dergisi, 61(2), 111-117, 2014.

18. Samour, J. Diagnostic value of hematology. Clinical avian medicine, 2, 587-609, 2006.

19. Ukpabi, U. H. Haematology and Blood Chemistry of Laying Hens Fed Raw Anthonatha Macrophylla Seed Meal Based Diet. Int. Journ. Of Agric. Anr Rur. Dev., 18(2): 2279-2286, 2015

20. Nodu, M. B., Okpeku, M., Akpoveta, Z. A., Iroegbu, D. O. Evaluation of azadirachta indica leave extract on hematology and biochemical profiles, organs weight and growth parameters of broiler chickens. Journal of New Sciences, 32, 5, 1879-1884, 2016.

21. Wagner, E. C., Stables, C., Williams, T. The Journal of Experimental Biology, 211, 2960-2968, 2008 , https://doi:10.1242/jeb.017897 .

22. Suchy, P., Strakova, E., Vecerek, V., Sterc, P. Biochemical studies of blood in hens during the laying period. Czech Journal of Anim. Science-UZPI (Czech Republic). 46: 383-387, 2001.

23. Café, M. B., Rinaldi, F. P., Morais, H. R., Nascimento, M. R. B. M., Mundim, A. V., Marchini, C. F. P., Biochemical blood parameters of broilers at different ages 
under thermoneutral environment. World's Poultry Science Journal, 1, 143-146, 2012.

24. Neijat, M., Gakhar, N., Neufeld, J., House, J. D. Performance, egg quality, blood plasma chemistry of laying hens fed hempseed and hempseed oil. Poultry science, 93(11), 2827-2840, 2014.

25. Gyenis, J., Suto, Z., Romvari, R., Horn, P., Tracking the development of serum biochemical parameters in two laying hen strains-A comparative study. Archiv. Fur. Tierzucht., 49, 593-606, 2006.

26. Albokhadaim, I., Hematological and some biochemical values of indigenous chickens in Al-Ahsa, Saudi Arabia during summer season. Asian Journal of Poultry Science, 6(4), 138-145, 2012.

27. Pampori, Z. A., Iqbal, S., Haematology, serum chemistry and electrocardiographic
ARNAUDOV A., et al.

evaluation in native chicken of Kashmir. International Journal of Poultry Science, 6(8), 578-582, 2007.

28. Yalcın, S., Onbaşılar, E. E., Reisli, Z., Yalcin, S. Effect of garlic powder on the performance, egg traits and blood parameters of laying hens. Journal of the Science of Food and Agriculture, 86(9), 1336-1339, 2006.

29. Prasad, R., Rose, M. K., Virmani, M., Garg, S. L., Puri, J. P. Lipid profile of chicken (Gallus domesticus) in response to dietary supplementation of garlic (Allium sativum). International Journal of Poultry Science, 8(3), 270-276, 2009.

30. Avian hematology. Avail. At: http//www.scholar.cu.edu.eg/Avian hematology 